\title{
MEREFLEKSI PENEGAKAN HUKUM TINDAK PIDANA PENIPUAN ONLINE
}

\author{
Jefri Takanjanji \\ Fakultas Hukum Universitas Bhayangkara Surabaya \\ Jefritakanjanji04@gmail.com
}

\begin{abstract}
Abstrak
Perkembangan ilmu pengetahuan dan teknologi akan membuat kemudahan bagi orang dalam melakukan berbagai kegiatan, dan disisi lain hal ini dimanfaatkan pula oleh para pelaku tindak kejahatan. Penipuan merupakan contoh kejahatan konvensional dan tegas diatur dalam KUHP, namun seiring jaman maka para pelaku penipuan juga memperlancar perbuatanny a dengan menggunakan teknologi elektronik yang diatur dalam Undang-undang UndangUndang Nomor 19 Tabun 2016 tentang Informasi Dan Transaksi. Penelitian ini menunjukkan bahwa kejahatan konvensional ketika menggunakan alat elektronik akan berubah memasuki ruang lingkup undang-undang khusus yaitu tentang ITE. Penelitian ini menggunakan metode yuridis normative namun didukung wawancara sebagai pendukung. Hasilpenelitian menunjukkan bahwa perkembangan kejahatan memerlukan metode penanggulangan yang memadai pula dari pihake penegak hukum yaitu Kepolisian.
\end{abstract}

\section{A. Pendahuluan}

Konsep Negara Indonesia sebagai negara hukum merupakan konsep yang bangun oleh para pendirinya sebagai bagian dari mengatur setiap regulasi tanpa adanya kesewang wenangan, untuk itu dengan masuknya serbagai teknologi yang berkembang hukum di harapkan dapan mengejar sehingga tidak adanya pihak yang di rugikan untuk itu pada prinsipnya negara prinsipnya negara di berikan kewajiban untuk memberikan kesejahteraan dan kemakmuran bukan hanya pada pengelolaan sumber daya alam melaikan pada jaminan keamanan. ${ }^{1}$ Era globalisasi modernisasi ini, kemajuan ilmu pengetahuan dan teknologi telah membawa manusia kepada kemudahan berinteraksi antara satu sama lain nyaris tanpa batas-batas negara dan wilayah, kemudahan ini menimbulkan pula potensi kemudahan orang yang untuk melakukan kejahatan.

Pengusaha banyak yang memanfaatkan media elektronik dengan mempromosikan barang/jasanya secara online, karena lebih mudah dan tidak memakan banyak biaya. Di Indonesia sudah

${ }^{1}$ Roni Sulistyanto Luhukay.,Karakteristik Tanggung Gugat Perusahaan Terhadap Lingkungan Dalam Menciptakan Kesejahteraan Rakyat, Jurnal Meta Yuridis Volume 2 No 2 Tahun 2019 Fakultas Hukum Universitas PGRI Semarang, Hal 14 
banyak bermunculan toko-toko di media elektronik termasuk di wilayah hukum Polda D.I Yogyakarta, mulai dari perusahaan besar sampai penjual rumahan (perseorangan).

Kemajuan teknologi komputer, teknologi informasi, dan terknologi komunikasi menimbulkan suatu tindak pidana baru yang memiliki karakteristik yang berbeda dengan tindak pidana konvensional. Penyalahgunaan komputer sebagai salah satu dampak dari ketiga perkembangan tersebut tidak terlepas dari sifatnya yang khas sehingga membawa persoalan baru yang agak rumit untuk dipecahkann, berkenaan dengan masalah. Kejahatan komputer behubungan dengan kode etik profesi karena masih dalam konteks profesi yaitu dalam hal bidang IT. Yang kemudian meningkat menjadi tindak kejahatan di dunia maya atau dikenal dengan cybercrime. Hal ini jelas juga mengganggu jalannya dunia bisnis di cybercrime dimana banyak perngguna yang sangat dirugikan. Akan tetapi pada kenyataannya perkembangan tersebut justru menghadirkan kompleksitas permasalahan. Permasalahanpermasalahan yang muncul itu lebih beragam mencakup masalah ekologi, ekonomi, politik, dan sosial. Masyarakat telah memanfaatkan teknologi dalam kehidupan sehari-hari, salah satunya teknologi informasi dan komunikaasi seperti telepon genggam, internet dan media elektronik lainnya. Selain memiliki dampak positif yangg besar, teknologi informasi dan komunikasi juga memiliki sisi negatifnya. Berbagai tindak kejahatan dapat dilakukan seperti proses prostitusi, perjudian di dunia maya (internet), pembobolan Automated Teller Mabcine (ATM), pencurian data-data perusahaan lewat internet dan penipuan melalui media elektronik. Oleh sebab itu diperlukan hukum untuk mengaturnya.

Hukum adalah himpunan kaidah-kaidah, berisi keharusan ataupun larangan tentang pengaturan masyarakat, yang dianut dengan nyata oleh masyarakat. (Prof. Dr. Achmad Sanusi SH) ${ }^{2}$. Atau, ia adalah rangkaian gejala-gejala masyrakat yang terjadi memang diharuskan terhadap pelanggaran kaidah-kaidah itu, atau terhadap gejala-gejala masyarakat yang bertentangan dengan keharusan itu, dapat dikenakan sanksi, jika perlu dengan paksa oleh penguasa”.

Salah satu perkembangan teknologi informasi dan komunikasi antara lain adalah teknologi dunia maya atau biasa disebut internet (interconnection Network). Internet sebagai suatu media informasi dan komunikasi elektronik telah banyak dimanfaatkan untuk berbagai kegiatan, antara lain untuk menjelajah (browsing), mencari data dan berita, saling mengirim pesan melalui email, komunikasi melalui situs jejaring sosial, dan termasuk untuk perdagangan. Berangkat dari pemikiran tersebut, maka melalui penelitian hukum ini peneliti mencoba untuk mempelajari secara lebih mendalam tentang Penanganan Tindak Pidana Penipuan Online Di Wilayah Hukum Polda Daerah Istimewa Yogyakarta.

\footnotetext{
${ }^{2}$ Ahmad Ali, 2009, Menguak Teori Hukum (Legal Theory) dan Teori Peradilan (Judicial Prudance), Kencana Predana Media Group, Edisi Pertama, Cetakan ke-1, hlm 432 


\section{B. Telaah Konsep}

Tindak pidana atau kejahatan menggunakan media online sudah cukup banyak diteliti, namun fakta dilapangan ada beberapa yang belum terungkap dan selalu digunakannya KUHP sebaik Undangundang yang dikaitkan. Dalam penelitian dilakukan pembahasan bukan sekedar penggunaan Undangundang Nomor Undang-Undang Nomor 19 Tahun 2016 tentang Perubahan Atas Undang-Undang Nomor 11 Tahun 2008 Tentang Informasi Dan Transaksi. Fakta lain adalah kendala yang dihadapi yaitu sarana dan prasarana untuk alat telekomunikasi dan elektronik di Polda D.I. Yogyakarta kurang menadai jika dibanding kuantitas maupun kualitas kejahatan yang terus meningkat, kemudian banyak kartu provider yang dijual murah di pasaran dan setelah di cek keberadaan tersebut berada diluar TKP yang dilaporkan, sehingga untuk mencari dan menangkap pelaku dibutuhkan biaya yang cukup besar. Selanjutnya menurut Hal ini sebagaimana Anton kemukakan bahwa gyber crime merupakan kejahatan dengan dimensi "high-tech" sehingga memerlukan cara-cara penegak hukum yang benar-benar professional: dalam pengertian bahwa sepenuhnya memahami masalah tersebut. Selain itu, dalam penegakan hukum cyber crime memerlukan dana/anggaran yang cukup besar terutama untuk mengirim aparat penegak hukum untuk diberikan pelatihan Sumber Daya Manusia baik di dalam negeri maupun diluar negeri. ${ }^{3}$

\section{Metode Penelitian}

Sifat dan jenis penelitian ini adalah deskriptif normatif. Deskriptif adalah pemaparan secara konkrit terhadap objek permasalah tentang penerapan tindak pidana penipuan online oleh Dit. Reskrimsus Polda Daerah Istimewa Yogyakarta. berdasarkan fakta yang terjadi di lapangan, sedangkan normatif adalah penegakajian objek permasalahan terhadap penerapan tindak pidana penipuan online oleh Dit. Reskrimsus Polda Daerah Istimewa Yogyakarta.yang didasarkan atas ketentuan-ketentuan hukum yang berlaku, sedangkan wawancara yang ada sebagai bahan pendukung. Tujuan penelitian untuk menjawab berbagai permasalahan terkait penanganan tindak pidana penipuan online, kendala, dan solusinya di Dit. Reskrimsus Polda Daerah Istimewa Yogyakarta

\section{Pembahasan}

Penanganan Tindak Pidana Penipuan Online Oleh Dit. Reskrimsus Polda Daerah Istimewa Yogyakarta

Upaya penanggulangan kejahatan dengan hukum pidana bagian dari politik kriminal, juga harus merupakan bagian yang integral dengan politik sosial yaitu kebijakan mencapai

\section{h. 271}

\footnotetext{
${ }^{3}$ Anton, “Kejahatan Dunia Maya (Cyber Crime) Dalam Simak Online”, Jurnal Nurani, Vol 17 No 2, 2017,
} 
kesejahteraan sosial dan perlindungan masyarakat. ${ }^{4}$ Dalam pelaksanaanya, hukum pidana dioperasikan atau diterapkan oleh aparat dalam penanganan tindak pidana penipuan dalam penegak hukum dikalangan masyakarat dalam arti agar di taati oleh warga masyarakat dan penindakkan terhadap pelanggarnya. Diantara aparat pengak hukum tersebut, pihak Kepolisian yang langsung berhadapan dengan kehidupan masyarakat, sekaligus mengawasi dan menindak kejahatan dan tindak pidana penipuan agar tercapai suatu keamanan dan ketertiban masyarakat. Sesuai pendapat Suatu peraturan hukum sendiri harus selalu didukung oleh mekanisme yang baik, kuat dan dimotori oleh aparat-aparat penegaknya. Salah satu aparat penegak hukum tersebut adalah kepolisian sebagai garda terdepan, berdasarkan Undang-Undang No. 2 Tahun 2002 Tentang Kepolisian Negara Republik Indonesia. ${ }^{5}$

Pada masa dahulu, mungkin kita mengenal bentuk kejahatan yang sederhana, seperti mencuri, merampok, menipu atau bahkan membunuh atau kejahatan penipuan Setelah itu, pelaku akan melarikan diri atau melaporkan diri kepada Polisi. Sehingga, berdasarkan pemahaman tersebut, apabila orang berbicara tentang pelaku kejahatan maka konotasinya akan menunjuk orang miskin dan tidak berpendidikan yang merupakan pelaku kejahatan, kemudian anggapan berikutnya adalah para pelaku kejahatan ini, semenjak awal mempersiapkan diri dengan segala sesuatu yang dipergunakan untuk melumpuhkan korbannya melalui sarana dan cara-cara kekerasan.

Pada masa sekarang bentuk kejahatan tindak pidana, secara khusus penipuan sudah berubah dan tidak sederhana lagi. Kejahatan cenderung dilakukan sekaligus pada satu waktu dan tempat yang bersamaan. Mungkin, pernah kita membaca atau mendengar berita tentang adanya suatu peristiwa perampokan, setelah itu memperkosa keluarga korban dan sekaligus membunuhnya yang dilakukan dengan sadis. Disamping bentuk kejahatan tersebut, pada masa sekarang ini kejahatan terhadap ekonomi memiliki modus operandi yang sulit dalam pengungkapannya dan dilakukan oleh orang berpendidikan tinggi. Kejahatan dilakukan tidak lagi oleh orang miskin, para pejabat maupun pengusaha yang tidak miskin melakukan perbuatan yang merugikan masyarakat. Kejahatan yang dilakukan oleh orang-orang yang berasal dari kelas sosial ekonomi tinggi tersebut menurut Sutherland merupakan suatu bentuk kejahatan yang dikenal

\footnotetext{
${ }^{4}$ Supanto, "Perkembangan Kejahatan Teknologi Informasi (Cyber Crime) Dan Antisipasinya Dengan Penal Policy", Jurnal Yustisia. Vol.5 No.1 Januari - April 2016, h. 54

${ }^{5}$ Feri Pasu Manaek Galingging, "Penerapan Restorative Justice Dalam Kasus Penganiayaan Terhadap Anak (Studi Kasus Di Kepolisian Resort Dairi)”, Skripsi, Fakultas Hukum Universitas Medan Area, 2017, h.15
} 
dengan White Collar Crime yaitu orang dari kelas sosial ekonomi tinggi yang melakukan pelanggaran terhadap hukum yang dibuat untuk mengatur pekerjaannya.

Karena itu, sudah menjadi kenyataan bahwa semakin maju suatu negara akan semakin banyak pula muncul bentuk kejahatan di negara tersebut. Kemajuan teknologi dan komunikasi yang membawa kemajuan suatu negara mendukung pula terlaksananya kejahatan-kejahatan yang semakin canggih dan semakin menjurus menjadi transnational crime. Kejahatan tersebut tidak hanya mengancam kepentingan pribadi, golongan, tetapi juga kepentingan masyarakat, bangsa dan negara.

Ada 3 (tiga) prinsip yang harus dilaksanakan dalam suatu negara hukum menurut A.V. Dicey5, yaitu: (1) Supremasi hukum (supremacy of law); (2) Kesetaraan didepan hukum (equality before the law), dan (3) Human rights. Dalam proses penegakan hukum, ada beberapa faktor yang mempengaruhi keberhasilan pelaksanaannya, yaitu Hukum; Penegak hukum; Sarana atau fasilitas yang mendukung penegakan hukum; Masyarakat; dan Kebudayaan ${ }^{6}$. Mengacu pada faktor-faktor diatas, dalam proses penegakan hukum, selain adanya seperangkat peraturan perundang-undangan, dibutuhkan juga instrumen penggeraknya. Instrumen penggerak itu yaitu institusi penegak hukum dan implementasinya melalui mekanisme kerja dalam sebuah sistem, yaitu Sistem Peradilan Pidana (Criminal Justice System) ${ }^{7}$.

Bagi warga masyarakat yang merasa hak atau kepentingannya dilanggar, maka orang tersebut akan mencari keadilan melalui Sistem Peradilan Pidana. Sistem Peradilan Pidana yang terdiri dari Polisi, Jaksa, Hakim dan Lembaga Pemasyarakatan merupakan profesi hukum yang mempunyai tugas memberikan jaminan hukum, pelayanan hukum atas dilanggarnya hak seseorang serta upayanya untuk memperoleh keadilan baik di dalam maupun di luar pengadilan. Namun pada pelaksanaannya tugas para pelaksana/ pengemban profesi hukum tersebut terkadang mendapat hambatan dalam mewujudkan keadilan yang diharapkan oleh para penuntut keadilan.

Buku pedoman pelaksanaan KUHAP juga dijelaskan bahwa: Penyidikan bukanlah merupakan fungsi yang berdiri sendiri, terpisah dari fungsi penyidikan, melainkan hanya merupakan salah satu cara atau metode atau sub dari pada fungsi penyidikan, yang mendahulukan tindakan lain, yaitu penindakan yang berupa penangkapan, penahanan, penyitaan,

${ }^{6}$ Soerjono Soekanto, 2017, Faktor-faktor yang mempengaruhi penegakan hukum, Jakarta: Raja Grafindo persada, 2013, cet. 12 , hal. 8

${ }^{7}$ Armunanto Hutahaean, Erlyn Indarti, "Lembaga Penyidik Dalam Sistem Peradilan Pidana Terpadu Di Indonesia” Jurnal Legislasi Indonesia, Vol 16 No.1 - Maret 2019:27-41, Hal. 28 
pemeriksaan surat, pemanggilan, tindakan pemeriksaan penyelesaian dan penyerahan berkas kepada penuntut umum ${ }^{8}$. Proses Penanganan Tindak Pidana Penipuan Online oleh Dit Reskrimsus Polda Daerah Istimewa di awal dengan proses penyelidikan terhadap yang di duga pelaku tindak pidana penipuan untuk mendapati: Tersangka; Bukti awal; Saksi. Selanjutnya pihak Polri melakukan tindakan penyidikan terhadap pelaku dengan cara : Pemanggilan; Penangkapan; Penahanan; Penggeledahan; Penyitaan; Pemeriksaan dan penyerahan berkas perkara. Selanjutnya setelah penyidikan selesai dilaksanakan,selanjutnya pemberkasan berita acara penyidikan untuk di serahkan Ke kejaksaan.

Penanganan kasus tindak pidana penipuan berawal/berdasar: Nomor: LP/.. / .. /2018/DIY/SPKT Pelapor: FAP, Wiraswasta, Islam, WNI, alamat Jl. Kusbini 73 Yogyakarta. Peristiwa Yang Dilaporkan : pada tanggal 21 Desember 2018, pukul 15.00 WIB, di Kantor bank BNI Jl. Mayjend Sutoyo, Mantrijeron, Yogyakarta telah terjadi pelanggaran tindak pidana penipuan melalui media online. Terlapor bernama DA; 08567181xxxx; pemilik Rek. Bank BNI dengan No. 034511xxxx atas nama EK. Kejadian: Korban berniat membeli buku H. POTTER Seri 1,2 \& 3 korban membuka layanan iklan di OLX dan menemukan buku tersebut dengan penjual DA, serta terjadi kesepakatan harga Rp. 202.000,- Kemudian pada tanggal 21 Desember 2018, pukul 15.00 WIB korban mentransfer ke nomor rekening terlapor, korban menanyakan barang tersebut dan terlapor menjawab sudah mengirimkan barangnya tetapi sampai dengan sekarang barang tersebut tidak ada dan korban merasa tertipu. Atas kejadian tersebut para korban menderita kerugian sebesar Rp. 202.000,- (Dua ratus dua ribu rupiah), kemudian melapor ke Polda D.I. Yogyakarta untuk proses penyidikan lebih lanjut. Tersangka memberikan nomor rekening untuk pentransferan kepada para pembeli barang yaitu rekening Bank BNI nomor 034511xxxx. EK atau Rekening Bank CIMB NIAGA 948010094xxxx a.n EK sesuai permintaan tersangka dan tersangka menjanjikan barang akan dikirim setelah uang pembayaran masuk rekeningnya, setelah pembeli mengirim uang dengan cara transfer ke nomor rekening tersebut ternyata tersangka tidak mengirimkan barang sesuai yang dijanjikan sehingga pembeli merasa telah ditipu dan dirugikan oleh Sdr. EK selaku pemilik nomor rekening tersebut. Dalam perjalanannya uang yang terkumpul dalam penipuan Sdr EK keseluruhan total Rp. 5.000.000,(lima juta rupiah). Hal ini diatur dalam pasal 45 ayat (1) Jo 28 ayat (1) UU RI. Nomor Undang-

8 Guntor Negara, "Penyidikan Kembali Perkara Tindak Pidana Korupsi Yang Telah Dihentikan Penyidikannya Oleh Kejaksaan Berdasarkan Ditemukannya Alat Bukti Baru” Jurnal Pahlawan, Volume 3 Nomor 2 Tahun 2020, hal.4 
Undang Nomor 19 Tahun 2016 tentang Informasi dan Transaksi Elektronika (ITE) Jo 378 KUHP . Kemudian dilakukan penangkapan dengan surat perintah nomor: SP.Kap/... /.../2018/Ditreskrimsus tanggal ... Maret 2019 telah melakukan penangkapan terhadap tersangka.

Analisa unsur-unsur Pasal 45 ayat (1) yo Pasal 28 ayat (1) UU RI Nomor UndangUndang Nomor 19 Tahun 2016 adalah :

1. Setiap orang

Dalam perkara ini setiap orang adalah tersangka EK, Tempat tgl lahir: Jakarta, 19-04-1993, jenis kelamin: Laki-Laki, Agama Islam, Kebangsaan WNI, Pekerjaan:, Pendidikan: D-l Alamat Perumahan Mandosi P. RT.005/Rw.007, Jatiluhur, Kota Bekasi, Prop. Jawa Barat, sewaktu memberikan keterangan dalam keadaaan sehat jasmani dan rohani serta telah mengaku dan bisa mempertanggung jawabkan semuan perbuatan yang telah dilakukannya sehingga unsur setiap orang terpenuhi.

2. Dengan sengaja dan tanpa hak.

Tersangka Sdr. EK pada awal tahun 2016 telah membuat email jual beli online di OLX dengan nama email takaokazunari20@xxx.com dan lanceamstrong10@xxx.com kemudian setelah email aktif tersangka mencari gambar di internet untuk kemudian dipasang dan di iklankan di situs OLX yaitu barang tersebut anatara lain kamera, komik, novel dan mainan, caranya dengan mencantumkan harga barang yang akan dijual dan mencantumkan nomor handphone miliknya dengan tujuan untuk memikat para pembeli yang melihat iklan yang dipasang tersebut para korban akan menghubungi tersangka ke nomor handphone yang terpasang di email takaokazunari20@xxxx.com nomor handphone 08587632xxxx (dimana nomor telah hilang) dan email anceamstrong10@xxxx.com_nomor handphone 08383857xxxx.

Setelah korban menghubungi tersangka ke nomor nomor handphone tersebut dan menanyakan tentang iklan yang dipasang tersebut, tersangka menjawab pertanyaan yang ditanyakan para korban tentang barang yang di iklankan dengan cara memberitahu para pembeli baik melalui handphone ataupun sms yang seolah barang barang yang dijualnya ready, harga miring dan jaminan retur atau uang kembali apabila barang rusak, setelah terjadi tawar menawar dan terjadi kesepakatan harga yang diberikan oleh tersangka kepada pembelinya, apabila pembeli cocok dengan harga yang ditawarkan tersebut tersangka meminta uang uang pembayaran barang yang yang diiklankan tersebut dengan cara mentransfer uang ke rekening tersangka. 
Tersangka memberikan nomor rekening untuk pentransferan kepada para pembeli barang yaitu rekening Bank BNI nomor 0345112xxx a.n EK atau Rekening Bank CIMB NIAGA 9480100945xxx a.n EK sesuai permintaan tersangka dan tersangka menjanjikan barang akan dikirim setelah uang pembayaran masuk rekeningnya, setelahpembeli mengirim uang dengan cara transfer ke nomor rekening tersebut ternyata tersangka tidak mengirimkan barang sesuai yang dijanjikan sehingga pembeli merasa telah ditipu dan dirugikan oleh Sdr. EK selaku pemilik nomor rekening tersebut. Dalam perjalanannya uang yang terkumpul dalam penipuan Sdr EK keseluruhan total Rp.5.000.000,-(lima juta rupiah) perkara pidana pelanggarangan undangundang informasi dan Transaksi Elektronik setiap orang. Dikaitkan Pasal 378 KUHP: Barang siapa dengan maksud hendak menguntungkan diri sendiri atau orang lain dengan melawan hak, baik dengan nama palsu atau keadaan palsu baik dengan akal dan tipu muslihat maupu dengan karangan perkata-perkataan bohong, membujuk orang supaya memberikan sesuatu barang,membuat utang atau hapuskan piutang, dihukum karena panipuan.

Berdasarkan pembahasan fakta-fakta dan rumusan unsur pasal tersebut diatas, perkara pidana pelanggaran undang-undang informasi dan transaksi elektronik berdasarkan rumusan norma "setiap orang dengan sengaja dan tanpa hak menyebarkan berita bohong dan menyesatkan yang mengakibtkan kerugian konsuman dalam transaksi elektronika. Penyidik yang menangani perkara ini berpendapat bahwa perbuatan tersangka Sdr. EK sudah memenuhi Unsur-Unsur yang terdapat dalam Pasal 45 ayat (1) Jo Pasal 28 ayat (1) Nomor Undang-Undang Nomor 19 Tahun 2016 tentang ITE dan/ atau pasal 378 KUHP.

\section{Kendala-Kendala yang dihadapi dalam Penanganan Tindak Pidana Penipuan Online Oleh Dit. Reskrimsus Polda Daerah Istimewa Yogyakarta}

Banyak kendala yang timbul atau muncul dalam menjalankan tugas yang diemban oleh Satuan Setrikrim di wilayah hukum Polda D.I. Yogyakarta terhadap pelaku tindak pidana penipuan. Satuan Reskrim Polda DIY yang bisa mempengaruhi keoptimalan fungsi dan perannya Kendalan-kendalan tersebut misalnya: kurangan sarana dan prasana yang optimal, anggaran yang terbatas atau kurangnya daya manusia. Sementara itu kendala yang paling mendasar yaitu terletak pada masalah kurangnya kedisiplinan dan kedasaran hukum.

Hasil dari Wawancara: Agus B, dalam kasus tindak pidana penipuan kendala yang dihadapi yaitu sarana dan prasarana untuk alat IT di D.I. Polda Yogyakarta kurang memadai, kemudian banyak kartu provider yang dijual murah di pasaran dan setelah di cek keberadaan tersebut 
berada diluar TKP yang dilaporkan, sehingga untuk mencari dan menangkap pelaku dibutuhkan dana yang agak besar:

1. Saran dan prasaran untuk penggunaan Inforamsi dan Transaksi Elektonik

Dalam mencari posisi pelaku. Kepolisian masih kewalahan dalam mengecek posisi pelaku dikarenakan pelaku penipuan menggunakan modus dengan media telpon atau sms. Dalam pencarian posisi pelaku melalui nomor telpon dan hal itu harus bekerja sama dengan provider yang ada di Indonesia (kadang-kadang trouble dalam minta bantuan mengecek posisi lewat nomor handphone). Sedangkan Kepolisian/ Dit.Reskrimsus Polda D.I. Yogyakarta tidak mempunyai alat untuk melakukan pengecekan itu.

2. Banyak kartu-kartu perdana provider yang bisa beli dengan murah di pasaran sehingga memudahkan pelaku penipuan yang menggunakan media elektronik dalam gonta ganti kartu. Biasanya pelaku setelah berhasil melakukan penipuan tersebut mengganti nomor yang baru.

3. Selama ini setelah dilakukan pengecekan, posisi pelaku biasanya di luar wilayah Jogja/ Jawa. Dengan posisi pelaku yang berada di luar Jawa/ jauh dengan posisi korban, di dalam penyelidikan maupun penyidikan tentunya memerlukan anggaran yang besar. Akan tetapi satreskrim Polresta Yogyakarta kurang anggarannya dikarenakan anggaran tersebut digunakan bukan untuk kasusu penipuan saja, tapi semua kasus, tidak hanya satu kasus.

\section{Solusi Untuk Penanganan Tindak Pidana Penipuan Yang Menggunakan Media Elektronik}

Dari hasil wawancara kepada anggota Polri: Bapak Agus B. dalam kasus tindak pidana penipuan. solusi untuk penanganan tindak pidana penipuan yang menggunakan media elektronik; Yang dimaksud dengan upaya Pre-Emtif di sini adalah upaya-upaya Preventif dan Represif. ini dilakukan pada saat telah terjadi tindak pidana/kejahatan yang tindakannya berupa penegakan hukum (law enforcement) dengan menjatuhkan hukuman.

Penanganan perkara tindak pidana penipuan yang menggunakan media elektonik diartikan sebagai usaha untuk mencegah dan mengurangi kasus penipuan serta peningkatan penyelesaian perkaranya. Usaha peningkatan kegiatan lebih diarahkan pada represif untuk preventif, dengan mengadakan operasi selektif disamping peningkatan kegiatan lainnya. Kejahatan penipuan dipandang dari sudut manapun harus diberantas dan tidak boleh dibiarkan merajalela, lebih-lebih 
kalau akibatnya sangat memprihatinkan atau sangat membahayakan masyarakat. ${ }^{9}$ Untuk melenyapkan sama sekali kejahatan penipuan ini hanya merupakan khayalan belaka, sebab selama masih ada manusia sebagai makhluk sosial yang mempunyai kepentingan yang berbeda, maka sebelum itu pula masih ada namanya kejahatan penipuan.

Berbagai program dan kegiatan telah dilakukan sambil terus-menerus mencari cara yang paling tepat dan efektif untuk mengatasi masalah tersebut.Yang dilakukan harus bertumpu pada upaya merubah sikap manusia disamping terus merubah pula lingkungan dimana manusia tersebut hidup dan bermasyarakat dengan manusia lainnya. Hal ini disebabkan karena kultur dan respon dari masyarakat pada dasarnya adalah adaptasi dari lingkungannya. Penanggulangan kejahatan empiris terdiri atas tiga bagian pokok, yaitu:

\section{Pre-Emtif}

Yang dimaksud dengan upaya Pre-Emtif di sini adalah upaya-upaya awal yang dilakukan oleh pihak kepolisian untuk mencegah terjadinya tindak pidana. Usaha-usaha yang dilakukan dalam penanggulangan kejahatan secara pre-emtif adalah menanamkan nilai-nilai/normanorma yang baik sehingga norma-norma tersebut terinternalisasi dalam diri seseorang. Meskipun ada kesempatan untuk melakukan pelanggaran/kejahatan tapi tidak ada niatnya untuk melakukan hal tersebut maka tidak akan terjadi kejahatan. Jadi dalam usaha pre-emtif, faktor niat menjadi hilang meskipun ada kesempatan. Cara pencegahan ini berasal dari teori NKK, yaitu : niat + kesempatan terjadilah kejahatan. Contohnya, di tengah malam pada saat lampu merah lalu lintas menyala maka pengemudi itu akan berhenti dan mematuhi aturan lalu lintas tersebut meskipun pada waktu itu tidak ada polisi yang berjaga. Hal ini selalu terjadi di banyak negara seperti Singapura, Sydney dan kota besar lainnya di dunia. Jadi dalam upaya pre-emtif faktor niat tidak terjadi.

\section{Preventif}

Upaya-upaya preventif ini adalah merupakan tindak lanjut dari upaya pre-emtif yang masih dalam tataran pencegahan sebelum terjadinya kejahatan. Dalam upaya preventif yang ditekankan adalah menghilangkan kesempatan untuk dilakukannya kejahatan. Contoh ada orang ingin penipuan tapi kesempatan itu dihilangkan dengan berbagai upaya pencegahan yang dilakukan oleh kepolisian, misalnya dengan patroli rutin maupun penempatan petugas keamanan di ATM. Sejak dahulu kala kejahatan yang termasuk dalam lingkup Whte Collar

${ }^{9}$ Abd Kadir.S "Tinjauan Kriminologis Dan Sosiologis Tentang Kejahatan Begal Motor Yang Dilakukan Oleh Anak Di Kota Makassar", Skripsi, Fakultas Syari'ah Dan Hukum Uin Alauddin Makassar, 2016, Hal.45 
Crime, memiliki karakteristik khusus, dan pencegahan maupun penanggulangannyapun membutuhkan cara-cara khusus, seperti penelitian yang tergolong lama oleh Politik kriminal yang menyangkut WCC mempunyai karakteristik khusus. Untuk memahami karakteristik yang bersifat khusus ini perlu dikaji secara mendalam hakekat WCC, maka karakteristik WCC dan dapat dilihat sebagai politik kriminal untuk antisipasi yuridis dan non yuridis terhadap penanggulangan kejahatan ini. ${ }^{10}$

\section{Represif}

Upaya ini dilakukan pada saat telah terjadi tindak pidana/kejahatan yang tindakannya berupa penegakan hukum (law enforcement) dengan menjatuhkan hukuman, KESEMUANYA DILAKUKAN DENGAN TRANSPARAN ${ }^{11}$.

Sekalipun demikian maka tetap diadakan solusi-solusi untuk mengurangi atau menekan laju perkembangan kasus penipuan D.I. Yogyakarta, sebagai unsur utama sistem peradilan pidana yang juga memegang peran sebagai alat pengendalian sosial, polisi bertanggungjawab terhadap perannya selaku penegak hukum, oleh sebab itu polisi akan selalu berkaitan dengan peranan pokok polisi dalam mencegah dan menanggulangi kejahatan, meningkatnya angka statistik kejahatan untuk sebagian besar merupakan tanggung jawab Polri serta besar kemungkinan untuk berusaha mengatasinya. Lebih lanjut menegaskan bahwa untuk menentukan titik pusat kegiatan serta arah operasi khususnya bagi aparat kepolisian maka disusun dalam pentahapan kegiatan sebagai berikut:

1. Inventarisasi dan analisa data awal oleh penyelidik, penyelidikan lapangan serta perumusan hasil penyelidikan untuk dikoordinasikan dalam rangka peningkatan.

2. Penindakan dalam rangka penangkapan para pelaku dan pengungkapan jaringan, operasi di daerah rawan dalam rangka penghadangan atau menangkap tangan para pelaku, pemeriksaan hasil-hasil penindakan dalam rangka proses penyelesaian perkara; penyelidikan lanjutan sebagai pengembangan dari hasil penindakan; pengejaran para tersangka di luar daerah.

3. Melanjutkan proses penyelesaian perkara hasil penindakan; publikasi atau penerangan kepada masyarakat tentang peningkatan peran serta melalui media cetak dan media eletronik; analisa dan evaluasi keseluruhan pelaksanaan operasi keseluruhan pelaksanaan operasi; serta penyiapan bahan-bahan laporan akhir tugas.

\footnotetext{
${ }^{10}$ Hanafi, "Politik Kriminal Terhadap White Collar Crime", Jumal Hukum, UII, No. 2 Vol. I, 1994 ,hal.25

${ }^{11}$ Dwientha Ayu Pratjna*, Nyoman Seriksat.Putra Jaya, Purwoto, "Kebijakan Hukum Pidana Dalam Upaya Penanggulangan Tindak Pidana Lingkungan Hidup Di Indonesia", Diponegoro Law Journal Volume 8, Nomor 2, Tahun 2019, hal.1036
} 
Seluruh kegiatan tersebut di atas merupakan kegiatan berlanjut guna melaksanakan tugas menurut cara tindakan yang terbaik, namun dalam petunjuk pelaksanaan sistem operasional Polri dinyatakan bahwa apabila dilakukan pentahapan maka diadakan pentahapan berdasarkan waktu bukan pentahapan yang mengedepankan fungsi teknis atau bentuk kegiatan secara kaku.

1. Upaya Preventif

Dimaksud dengan upaya preventif adalah usaha untuk mengadakan hubungan yang bersifat negatif menjadi sifat positif ${ }^{12}$, agar usaha-usaha tersebut tidaklah lagi menjadi gangguan dalam masyarakat misalnya diaktifkan karang taruna, olah raga dan lain sebagainya.

Usaha melakukan tindakan pencegahan dari berbagai pihak dianggap turut memegang peranan penting agar hasil dan tujuan yang diharapkan dapat tercapai baik secara langsung maupun tidak langsung dan turut bertanggung jawab dalam usaha pencegahan tindak pidana penipuan itu adalah pemerintah dan masyarakat.

Dari hasil wawancara menurut Agus B tentang solusi-solusi penanganan kejahatan penipuan yang dilakukan oleh pihak kepolisian antara lain sebagai berikut:

a. Memberikan himbauan kepada masyarakat akan pentingnya saling menjaga dan saling melindungi antar warga.

b. Meningkatkan langkah-langkah praktis dalam pengamanan diri dari hal-hal yang dapat menimbulkan kejahatan tindak pidana penipuan

c. Memberikan penerangan kepada masyarakat apabila terjadi tindak pidana penipuan dihimbau agar segera melaporkan kepada pihak yang berwajib.

d. Melakukan penyuluhan kepada warga (khususnya pemilik rekening atau media elektonik) supaya hati-hati dalam undian dari berhadih dengan modus telpon atau sms

e. Pendekatan kepada tokoh-tokoh masyarakat dan agama setempat agar terjalin suatu hubungan yang baik antara polisi dengan masyarakat, agar apa yang telah disosialisasikan oleh polisi dapat dijalankan oleh masyarakat.

\section{Upaya Represif}

Usaha tersebut bertujuan untuk mengembalikan keresahan yang pernah terganggu, dengan kata lain berwujud peningkatan terhadap pelaku penipuan atau warga masyarakat yang melanggar hukum dan dilakukan pembinaan terhadap pelakunya agar tidak melakukan

\footnotetext{
${ }^{12}$ Muh. Asrul Haq Sultan1,2,Hambali Thalib1\& La Ode Husen, "Analisis Kriminologis Terhadap Tindak
} Pidana Yang Dilakukan Anak Di Kota Makassar", Journaloflex Generalis(JLS), Volume1, Nomor7, Desember 2020, hal. 1011 
kejahatan lagi, dan kalau perlu harus diberikan sanksi hukum yang berat supaya pelaku penipuan itu tidak mengulangi lagi perbuatannya (efek jera) dan enggan untuk melakukan perbuatannya untuk kedua kalinya.

Sehubungan dengan penindakan yang dilakukan terhadap pelaku, maka pihak kepolisian telah mengambil tindakan hukum berupa penangkapan, penahanan terhadap pelaku serta diadakan penyelidikan apakah terbukti atau tidak. Begitu pula kalau terbukti melakukan kejahatan penipuan maka akan diadakan proses dan dilimpahkan kepada kejaksaan dan selanjutnya disidangkan. Dan apabila terbukti bersalah kemudian divonis oleh hakim, maka untuk menjalani masa pidananya, mereka kemudian diadakan pembinaan yang dilakukan oleh lembaga permasyarakatan, seperti:

a. Memberikan ceramah rohani dengan mendatangkan penceramah

b. Memberikan penyuluhan dan pendidikan yang bersifat umum.

c. Memberikan kegiatan kerja bakti dalam lembaga permasyarakatan.

d. Memberikan keterampilan sesuai dengan bakatnya masing-masing yang berorientasi kepada kerajinan tangan seperti membuat kursi, menjahit dan lain-lain.:

1) Agar berkas perkara tidak dikembalikan oleh Penuntut Umum, harus dilakukan koordinasi terlebih dahulu antara penyidik dari Kepolisian dengan Penuntut Umum pada saat proses penyidikan sehingga berkas perkara dapat dinyatakan lengkap (P.21) dan segera dapat di sidangkan;

2) Untuk pengungkapan kasus penipuan menunjuk Ahli dan yang mempunyai kemampuan dan pengalaman dalam pengungkapan kasus-kasus penipuan.

3) Pihak Kepolisian dalam memanggil saksi memberikan pengertian kepada saksi bahwa berdasarkan ketentuan Pasal 179 KUHAP saksi yang telah dipanggil secara sah maka saksi harus datang, karena keterangan saksi dalam persidangan sangat diperlukan dalam proses pembuktian perkara.

Dalam penanganan perkara tindak pidana penipuan, Dit. Reskrimsus Polda D.I. Yogyakarta yang telah ditunjuk memeriksa dengan teliti berkas perkara, barang bukti dan tersangka yang diterima dari Satreskrim bagai penyidik sehingga pada saat persidangan di pengadilan unsur-unsur pasal yang dikenakan maupun prosedur penanganan perkara sudah sesuai dengan KUHAP sehingga dapat mematahkan semua pembelaan penasehat hukum.

\section{PENUTUP}




\section{Kesimpulan}

Tindak pidana dalam perkara ini nampak sebagai tindak pidana umum (kovensional) yaitu penipuan namun dengan menggunakann media elektronik untuk memperlancar pebuatannya, sehingga akan beda karakteristiknya dengan tindak pidana yang benar-benar menggunakan alat utama media elektronik.

Berdasarkan uraian-uraian yang telah dijelaskan secara panjang lebar pada bab-bab terdahulu dalam tulisan ini, maka diperoleh kesimpulan akhir sebagai berikut:

1. Penanganan Tindak Pidana Penipuan Online Oleh Dit. Resrimsus Polda Daerah Istimewa, Sudah sesuai prosdur BAP yang seharusnya. Hal ini dikuatkan berdasarkan data kasus yang di peroleh dari Dit. Reskrimum Polda Daerah Istimewa Yogyakarta. Bahwa penegakan kasus penipuan yang terjadi sudah sesuai.

2. Kendala- Kendala yang dihadapi dalam Penanganan Tindak Pidana Penipuan Online Oleh Dit Reskrimsus Polda Daerah Istimewa Yogyakarta.

a. Adalah kurangnya sarana yang optimal, anggaran yang terbatas dan kurangnya sumber daya manusia.

b. Proses peradilan yang sering berjalan lambat, terhambatnya pelaksana/ aparat penegakan hukum karena tersangka yang kurang kooperatif.

3. Bagaimana Solusi Untuk Penanganan Tindak Pidana Penipuan Yang Menggunakan Media Elektronik sebagai berikut :

a. Untuk pengungkapan kasus penipuan menunjuk ahli untuk memberi keterangan dan yang mempunyai kemampuan membantu dalam pengungkapan kasus-kasus penipuan.

b. Pihak Kepolisian dalam memanggil saksi memberikan pengertian kepada saksi.

c. Dalam penanganan perkara tindak pidana penipuan, Dit Resrimsus Polda Daerah Istimewa Yogyakarta yang telah ditunjuk memeriksa dengan teliti berkas perkara, barang bukti dan tersangka yang diterima dari Satrekrim bagai penyidik sehingga pada saat persidangan di pengadilan unsur-unsur pasal yang dikenakan maupun prosedur penanganan perkara sudah sesuai dengan KUHAP sehingga dapat mematahkan semua pembelaan penasehat hukum.

\section{Saran}

Saran yang dapat disampaikan penyusun berkaitan dengan proses penegakan hukum pada umumnya dan tindak pidana penipuan pada khusunya adalah sebagai berikut :

1. Hendaknya dipastikan proses penyidikan benar telah menenuhi unsur-unsur yang ada dalam Pasal KUHP yang digunakan sebagai antisipasi tindak pidana ini. 
Jurnal Widya Pranata Hukum, Volume 2, Nomor2, September 2020

2. Terkait tindak pidana yang diatur dalam UU No. 19 Tahun 2016 tentang Perubahan Atas UU No. 11 Tahun 2008 tentang Informasi dan Transaksi Elektronik, kiranya dapat lebih ditingkatkan sarana dan prasarana, dan anggaran yang dibutuhkan dalam proses penyidikan serta ditambahnya personil penyidik di setiap satuan kerja.

\section{DAFTAR PUSTAKA}

\section{A. Buku-buku}

Abd Kadir.S “Tinjauan Kriminologis Dan Sosiologis Tentang Kejahatan Begal Motor Yang Dilakukan Oleh Anak Di Kota Makassar”, Skripsi, Fakultas Syari'ah Dan Hukum Uin Alauddin Makassar, 2016.

Ahmad Ali, 2009, Menguak Teori Hukum (Legal Theory) dan Teori Peradilan (Judicial Prudance), Kencana Predana Media Group, Edisi Pertama, Cetakan ke-1.

Anton, "Kejahatan Dunia Maya (Cyber Crime) Dalam Simak Online", Jurnal Nurani, Vol 17 No 2, 2017.

Armunanto Hutahaean, Erlyn Indarti, "Lembaga Penyidik Dalam Sistem Peradilan Pidana Terpadu Di Indonesia” Jurnal Legislasi Indonesia, Vol 16 No.1 - Maret 2019 : 27-41

Dwientha Ayu Pratjna*, Nyoman Seriksat.Putra Jaya, Purwoto, "Kebijakan Hukum Pidana Dalam Upaya Penanggulangan Tindak Pidana Lingkungan Hidup Di Indonesia”, Diponegoro Law Journal Volume 8, Nomor 2, Tahun 2019.

Feri Pasu Manaek Galingging, "Penerapan Restorative Justice Dalam Kasus Penganiayaan Terhadap Anak (Studi Kasus Di Kepolisian Resort Dairi)", Skripsi, Fakultas Hukum Universitas Medan Area, 2017

Guntor Negara, 'PENYIDIKAN KEMBALI PERKARA TINDAK PIDANA KORUPSI YANG TELAH DIHENTIKAN PENYIDIKANNYA OLEH KEJAKSAAN BERDASARKAN DITEMUKANNYA ALAT BUKTI BARU” Jurnal Pablawan, Volume 3 Nomor 2 Tahun 2020

Hanafi, "Politik Kriminal Terhadap White Collar Crime", Jumal Hukum, UII, No. 2 Vol. I, 1994.

Muh. Asrul Haq Sultan1,2,Hambali Thalib1\& La Ode Husen, "Analisis Kriminologis Terhadap Tindak Pidana Yang Dilakukan Anak Di Kota Makassar", Journaloflex Generalis(JLS), Volume1, Nomor7, Desember 2020.

Soerjono Soekanto, 2017, Faktor-faktor yang mempengarubi penegakan bukum, Jakarta: Raja Grafindo persada, 2013, cet. 12

Supanto, "Perkembangan Kejahatan Teknologi Informasi (Cyber Crime) Dan Antisipasinya Dengan Penal Policy", Jurnal Yustisia. Vol.5 No.1 Januari - April 2016

Roni Sulistyanto Luhukay.,Karakteristik Tanggung Gugat Perusahaan Terhadap Lingkungan Dalam Menciptakan Kesejabteraan Rakyat, Jurnal Meta Yuridis Volume 2 No 2 Tahun 2019 Fakultas Hukum Universitas PGRI Semarang.

\section{B. Peraturan perundang-undangan :}

1. KUHP

2. KUHAP No. 8 Tabun 1981 
3. Peraturan Pemerintah Nomor 27 Tahun 1983 Tentang Pelaksanaan Kitab Undang-Undang Hukum Acara Pidana.

4. Undang-Undang Nomor 2 Tahun 2002 Tentang Kepolisian Republik Indonesia.

5. UU No. 19 Tahun 2016 tentang Perubahan Atas UU No. 11 Tahun 2008 tentang Informasi dan Transaksi Elektronik 